\title{
Relationship Between Cyclic Citrullinated Peptide Antibodies Positivity and HLA-DRBI Shared Epitope Alleles in Patients with Rheumatoid Arthritis in Turkey
}

\author{
Türk Romatoid Artritli Hastalarda Siklik Sitrüline Peptit Antikor Pozitifliği ile \\ HLA-DRBI Ortak Epitop Alelleri Arasındaki ilişki
}

\author{
İdris Dayan' ${ }^{1}$ Canan Tıkız², Fatma Taneli³, Cevval Ulman³, Gürol Ulutaş³, Çiğdem Tüzün² \\ 1State Hospital, Physical Medicine and Rehabilitation, Tunceli, Turkey \\ 2University of Celal Bayar, Physical Medicine and Rehabilitation, Manisa, Turkey \\ ${ }^{3}$ University of Celal Bayar, Clinical Biochemistry, Manisa, Turkey
}

\begin{abstract}
Objective: The most characteristic genetic risk factors for rheumatoid arthritis (RA), the HLA-DRB1 shared epitope (SE) alleles, encode for a common amino acid sequence in the peptide-presenting part of the HLA class II molecule. These SE alleles have been described recently to be a risk factor for the development of antibodies against citrullinated proteins in RA. The current study was performed to investigate the association between the cyclic citrullinated peptide antibodies (anti-CCP) and HLA-DR1 HLA-DRB1 shared epitope alleles in patients with RA in Turkey.

Materials and Methods: Sixty patients with RA who were newly diagnosed or under conventional treatment in our clinic and 60 healthy volunteers as controls were enrolled in the study. In patients with RA anti-CCP levels were investigated with enzymelinked immunosorbent assay and HLA-DRB1 subtyping and SE was assessed by polymerase chain reaction. Only anti-CCP was measured in healthy volunteers.

Results: SE was positive in $50 \%$ of the patients with RA. Amongst the SE carriers, $30 \%$ of them were carrying double copy of SE. While anti-CCP was positive in $73,3 \%$ of patients with RA, this ratio was $0 \%$ in healthy volunteers. We determined that the existence of SE increases the positivity of anti-CCP $(\mathrm{OR}=4,3,95 \%[\mathrm{Cl}], \mathrm{P}=0.04)$, and a significant relationship was found between the anti-CCP positivity and the RF positivity. (OR=5,3, 95\% $[\mathrm{Cl}] \mathrm{P}<0.05)$.

Conclusion: The results of the present study revealed that Turkish patients with RA carrying SE with HLA-DRB1 genes is significantly related with the production of anti-CCP. The diagnostic sensitivity and specificity of anti-CCP for RA is determined as 73,3\% and $100 \%$ respectively. (Turk $J$ Rheumatol 2010; 25: 12-8)
\end{abstract}

Key words: Rheumatoid arthritis, anti-CCP, shared epitope, HLA-DR1

Received: 04.05.2009

Accepted: 03.08.2009

\section{Özet}

Amac: HLA DRB1 ortak epitop alelleri romatoid artritin (RA) en belirgin genetik risk faktörü olup, sınıf 2 HLA molekülünün peptid sunan bölümünde bir amino asit dizilimi tarafından kodlanmaktadır Son zamanlarda bu ortak epitop alellerinin RA'lı hastalarda sitrüllenmiș proteinlere karșı antikorların gelișimi için bir risk faktörü olabileceği öne sürülmektedir. Bu çalıșmada Türk toplumundaki RA'lı hastalarda siklik sitrüline peptid antikorları (anti-CCP) pozitifliğinin HLA-DRB1 allellerinin tașıdığı ortak epitopla olan ilișkisi araștırılmıștır.

Gereç ve Yöntem: Çalıșmaya kliniğimizde yeni tanı konulmus ya da tedavi altında olan 60 RA'lı hasta dahil edildi. Kontrol grubunu ise 60 sağlıklı gönüllü olușturdu. RA'lı hastalarda anti-CCP düzeyleri enzim-bağımlı immunosorbent ölçüm metoduyla, HLA-DRB1 tiplemeleri ve $\mathrm{OE}$ ölçümü polimeraz zincir reaksiyonu yöntemi ile araștırıldı. Sağlıklı gönüllülerde ise sadece anti-CCP düzeyleri ölçüldü.

Bulgular: Romatoid artritli hastalarda OE pozitifliği \%50 olarak saptandı ve bu hastaların \%30'u çift kopya OE tașıyordu. Anti-CCP pozitifliği RA'lı hastalarda \%73.3 iken, kontrol grubunda bu oran $\% 0$ olarak saptandı. OE varlığının anti-CCP pozitifliğini arttırdığı $(\mathrm{OR}=4.3, \% 95[\mathrm{Cl}], \mathrm{P}=0.04$ ) ve anti-CCP pozitifliği ile RF pozitifliği arasında anlamlı bir ilișkisi olduğu gözlendi (OR=5.3, \%95 [Cl] $\mathrm{P}<0.05$ ).

Sonuç: Çalıșmamızda Türk RA'lı hastalarda OE tașıyan HLA-DRB1 genlerinin anti-CCP üretimiyle anlamlı ilișkisi olduğu ve antiCCP'nin RA için tanısal duyarlılık ve özgüllüğünün sırasıyla $\% 73.3$ ve \%100 olduğu saptanmıștır. (Turk J Rheumatol 2010; 25: 12-8)

Anahtar sözcükler: Romatoid artrit, anti-CCP, ortak epitop, HLA-DR1

Alındığı Tarih: 04.05.2009 Kabul Tarihi: 03.08.2009 


\section{Introduction}

Rheumatoid arthritis (RA) is a chronic, inflammatory joint disease with autoimmune features, pointing to a contribution of genetic factors in the pathogenesis of RA. An association between RA and human lymphocytic antigen (HLA) complex, also known as the major histocompatibility complex (MHC), has long been observed in many different populations, and this is thought to account for approximately one third of the genetic component of RA susceptibility (1). In particular, HLA-DRB1 is the strongest susceptibility locus for RA. Widely recognized alleles that are major contributors to RA risk at DRB1 locus are DRB $1 * 0401, * 0405, * 0101, * 1001 * 1402$. All of these HLA-DRB1 alleles increasing risk of RA share common QKRAA, QRRAA and RRRAA amino acid sequences termed the shared epitope (SE) at positions 70-74. It has been suggested that this SE structure both causes a predisposition to RA development and increases joint destruction and extra-articular involvement (2-4). However, SE itself is not associated with RA in African, American and some Spanish populations (5-7). The effect of shared epitope presence on RA pathogenesis has not been fully understood as shared epitope containing alleles are not always associated with RA in different populations.

A considerable proportion of RA patients have autoantibody responses, especially rheumatoid factor (RF). More recently, another autoantibody response has received much attention. These antibodies are directed against cyclic citrullinated peptides (anti-CCP) and are highly specific for RA. These antibodies are stable over time, and are associated with joint destruction, the hallmark of RA $(8,9)$. Recently, it has been claimed by some researchers that immune response to citrullinated peptides may occur in the presence of shared epitopes. Experimental studies have shown that conversion of arginine to citrulline at the peptide side-chain position significantly increases the affinity of a peptide for binding to major histocompatability complex and can lead to activation of CD4 positive $T$ cells in transgenic mice having one of these shared epitope alleles. However, studies on human beings from various populations have reported contradictory results with respect to the association between HLA-DRB1 shared epitope and antiCCP in RA patients (10-13).

The aim of the current study was to investigate the frequency of anti-CCP and the association of anti-CCP positivity with HLA-DR1 SE alleles in patients with RA in Turkey.

\section{Materials and Methods}

The study population consisted of two groups: the first group included RA patients and the second group included healthy volunteer controls that had similar age and gender distribution. The first group included $60 \mathrm{RA}$ patients between 18-60 years who were newly diagnosed or under conventional treatment in our clinic according to American Collage of Rheumatology (ACR) classification criteria. Patients were heterogeneous with respect to age, duration of disease, age at diagnosis and received treatments. Those having active disease and those in remission were included in the study without any restriction. Among those included in the study, 45 were seropositive (RF+) and 15 were seronegative (RF-). Control group included 60 healthy volunteer women and men whose demographic findings were similar with RA group.

\section{Demographic and Clinical Parameters}

Histories of RA patients were taken, physical examinations were performed and presence of additional systemic disease was evaluated by carrying out routine laboratory examinations. Those having an additional inflammatory connective tissue disease, any malignancy or malignancy history, renal failure or liver failure were excluded from the study. Demographic features, duration of disease, age at diagnosis, previous treatments (non-steroidal anti-inflammatory medications, corticosteroids, disease modifying antirheumatic drugs (DMARD), additional history of systemic disease, family history and morning stiffness were recorded. Swollen and tender joints were examined and number of such joints was recorded. Those having deformities and extra articular involvement were recorded. Pain, self-evaluation of patients and physician's global assessment were measured by visual analog scale (VAS). In order to measure disease activity DAS28 scores were calculated by a special computer program using VAS pain, C-reactive protein (CRP) and number of swollen and tender joints. Radiographs of both hands were obtained in anteroposterior position, and Larsen scores were determined by a radiologist with Larsen-Dale method.

Venous blood samples were collected from patients after approximately 8-12 hours of starvation. Using these blood samples, erythrocyte sedimentation rate (ESR), complete blood count, serum fasting blood glucose, urea, creatinine, uric acid, triglyceride, cholesterol, alkaline phosphatase, and transaminase (ALT, AST) levels were measured. Moreover, some of the same blood samples were seperately placed into EDTA tubes for HLA analysis and into dry tubes for anti-CCP and RF. In order to detect the difference between anti-CCP levels of both groups, venous blood samples for anti-CCP level measurements were collected after 8-12 hours of starvation from the healthy control group, too. However, presence of shared epitope HLA-DRB1 alleles, which was examined in patient group, was not examined in healthy controls due to its high cost. Informed consent was obtained from all patients and controls. The study was approved by the local instutional research committee. 


\section{Laboratory Measurement methods}

Serum anti-CCP levels of the cases included in the study were measured by ELISA method using Immunoscan RA. Eurodiagnostica AB. Malmö/Sweden kit (2nd generation anti-CCP2 kit) was used and $0.25 \mathrm{U} / \mathrm{ml}$ was taken as the reference value. DNA extraction for shared epitope analysis and HLA typing was made manually with Invitek (Germany) Invisorb spin blood mini kit. Polymerase Chain Reaction (PCR) was performed on AB (Applied Biosystems) 2727 Thermal Cycler by using HLA-DRB1 Shared Epitope QKRAA/QRRAA/RRRAA kit of Aid Autoimmun Diagnostika GmbH company and hybridization was performed with Tecan ProfiBlot T47.

Measurement of ESR was made with Eriline AR Barcelona/SPAIN equipment using Westergreen method. CRP and RF were studied by turbidimetric method using UniCel Dx C800 equipment of Beckman Coulter (USA). RF was studied with Factor Reagent kit and CRP was studied with CRP Reagent kit. Reference ranges for ESR, CRP and $\mathrm{RF}$ were considered as 0-30 mm/hr, 0-0,5 mg/L and 0-20 IU/ $\mathrm{MI}$, respectively.

\section{Statistical analysis}

Data were recorded on SPSS11.0 windows package program. Continuous variables were presented as mean \pm standard deviation, categorical variables were presented in percentage. Student $t$ test and MannWhitney $U$ test were used for comparing two independent groups under the parametric and nonparametric test assumptions, respectively. Chi-square test was used in comparing two categorical variables. When there were at least one cell having an expected values were $<5$, results from the 2-tailed Fisher's exact chi-square test was used. The odds ratio (OR) and its $95 \%$ confidence interval was used to assess the risk.

\section{Results}

Forty-seven of RA patients were female (78\%). Average age of patients was $51.1 \pm 9.14$. Characteristics of the patients with RA is given in Table 1 . Share epitope was detected in 30 patients in this group. While 17 (56.6\%) of patients carried DR4, and 10 carried DR 1 alleles, HLADRB1 genes were found in 3 of them genes were found in 3 of them (two of them HLA-DR14 and one of them HLA-DRB 10). When amino acid sequences of RA patients with SE were studied, the amino acid sequence expressing SE the most frequently was QRRAA ( $n: 19)$. QKRAA and RRRAA amino acid sequences were observed in 13 and 2 patients respectively. When SE positive patients were evaluated with respect to homozygosity/heterozygosity the most frequently observed one was the simple heterozygosity type (21 patients). Nine patients carried double copy (total of homozygous and compound heterozygous patients) SE. With respect to age and gender, there was no significant difference between patient and control groups $(51.1 \pm 9.14$ and $48.8 \pm 7.5, p>0.05)$. In control group anti-CCP was negative (0\%) and in RA group antiCCP was found in a ratio of $73.3 \%(N=44)(p=0.0001)$. Accordingly, specificity and sensitivity of anti-CCP test were calculated as $100 \%$ and $73.3 \%$ respectively.

The average anti-CCP2 titer was found to be rather below the cut-off level of $25 \mathrm{IU} / \mathrm{mL}$ (average: $4.75 \pm 3.32 \mathrm{IU} / \mathrm{ml}$ ) in control group compared to RA group which had statistically significant high levels $(P<0,0001)$. When Ant-CCP positivity of SE positive patients was studied with respect to homosygozity/ heterozygosity subgroups (Table 2), it was observed that the largest group was the simple heterozygosity group. When we examined anti-CCP positivity of SE positive and SE negative patients (cut off levels taken as $25 \mathrm{IU} / \mathrm{ml}$ ), $86,7 \%$ of SE+ patients were found to be CCP positive and this was statistically significant $(p<0,02)$ (Table 2$)$. It was found that the presence of SE in RA patients carried a four-fold risk for antiCCP synthesis (OR=4.33 (1.2-15.6, Cl 95\%), p=0.039), (Table 3). In RA patients, there was no difference between SE (+) and SE (-) patients with respect to RF positivity. Additionally, the presence of SE was not found to carry a relative risk for RF synthesis (Table 3 ). The ratio of RA patients having at least one RF or anti-CCP positivity was $86.7 \%$. The ratio of having both antibodies was $61,6 \%$ (Table 4).

We observed that anti-CCP and RF positivities were also associated with each other. Both antibodies were positive in $37(61.6 \%)$ RA patients. At the same time, in RA patients, synthesizing one of the antibodies was associated with a 5,3

Table 1. Clinical, Laboratory and Radiological Characteristics of patients with Rheumatoid Arthritis

\begin{tabular}{lc}
\hline & $\begin{array}{c}\text { (mean } \pm \text { standard deviation), } \\
\text { (min-max) }\end{array}$ \\
\hline Age & $51.1 \pm 9.14$ \\
Male $(\mathrm{n}=13)$ & $22 \%$ \\
Female $(\mathrm{n}=47)$ & $78 \%$ \\
RF Positive & $75 \%(\mathrm{n}: 45)$ \\
Anti-CCP Positive & $73.3 \%(\mathrm{n}: 44)$ \\
HLA- DRB1 shared epitope (+) total & $50 \%(\mathrm{n}: 30)$ \\
\multicolumn{1}{c}{$\quad$ HLA-DR1 $\quad$ HLA-DR4 } & $16.7 \%(\mathrm{n}: 10)$ \\
\multicolumn{1}{c}{ HLA-DR10 } & $28.3 \%(\mathrm{n}: 17)$ \\
HLA-D14 & $1.7 \%(\mathrm{n}: 1)$ \\
Duration of disease (years) & $3.3 \%(\mathrm{n}: 2)$ \\
Pain intensity (mm, with VAS) & $8.07 \pm 8.53(0.30-33)$ \\
Larsen score & $41.58 \pm 25.62(0-90)$ \\
DAS-28 & $40.17 \pm 25.77(2-108)$ \\
\hline
\end{tabular}

VAS: Visual analog score, DAS: Disease activity score RF: Rheumatoid factor, anti-CCP : Cyclic citrullinated peptide antibodies, min-max: Minimum-Maximum 
fold increased risk of synthesizing the other antibody (OR (95\% Cl) 5.3(1.5-18.8), $p=0.015)$.

\section{Discussion}

Results obtained from the present study can be summarized as follows; 1-Shared epitopes were detected in half of the RA patients and the most frequent HLADRB1 subtype synthesizing shared epitope in these patients was HLA-DR4 gene, followed by HLA-DR1 gene. 2- It was observed that anti-CCP positivity was significantly higher in patients carrying shared epitope and odds ratio of anti-CCP synthesizing was found as 4.33 in RA patients carrying SE $(1.2-15.6,95 \% \mathrm{Cl}, \mathrm{p}=0.039)$. This has shown that, similar to the results reported in some populations, there is a significant positive correlation between two parameters in our population too. 3- Although anti-CCP was observed in a high percentage in RA patients, it was found in none of the healthy controls. Diagnostic sensitivity and specificity of anti-CCP for RA were 73,3\% and $100 \%$ respectively. $4-$ Moreover, it was observed that anti-CCP screening, along with RF, increased diagnostic sensitivity in RA.

Association of RA with shared epitope expressed by some HLA-DRB1 genes has been long known. Ratio of the association between these genes and the disease differs among different populations. While some studies performed in Europe emphasize that SE genes are associated with anti-CCP which is an early indicator of the

Table 2. Anti-CCP positivity ratios in subgroups with respect to homozygosity/heterozygosity in shared epitope positive patients (cut-off level $25 \mathrm{IU} / \mathrm{ml}$ )

\begin{tabular}{lccccc}
\hline Shared Epitope & $\begin{array}{c}\text { Anti-CCP-2 (-) } \\
(\mathbf{n}, \%)\end{array}$ & $\begin{array}{c}\text { Anti-CCP-2 (+) } \\
(\mathbf{n}, \%)\end{array}$ & Total \\
\hline Homozygous & $(1), \quad 3.3 \%$ & $(5)$, & $16.7 \%$ & $(6), 20 \%$ \\
Simple heterozygous & $(3)$, & $10 \%$ & $(18)$, & $60 \%$ & $(21), 70 \%$ \\
$\begin{array}{l}\text { Compound } \\
\text { heterozygous }\end{array}$ & $(0)$, & $0 \%$ & $(3)$, & $10 \%$ & $(3), 10 \%$ \\
Total & $(4), 13.3 \%$ & $(26), 86.7 \%$ & $(30), 100 \%$ \\
\hline
\end{tabular}

anti-CCP: Cyclic citrullinated peptide antibodies disease, there is not such a clear relation in publications from Latin America $(9-11,14)$. In our country, no study has been published to date on the association of HLADRB1 genes and Anti-CCP.

In the literature, the main HLA-DRB1 genes associated with RA are HLA-DR4 and HLA-DR1 respectively. In our study, consistent with the literature, the most frequently observed genes among shared epitope carrying genes were these too (HLA-DR4:17 patients and HLA-DR1: 10 patients). The number of patients having genes expressing shared epitope was $30(50 \%)$ in our study and 9 of these (15\% of all the patients) were observed to have double copy SE. Kınıklı et al. (4) found frequency of SE as 70,6\% in RA patients in our country. In the same study, the most frequently observed HLA type in those carying SE was HLA-DR4 with a ratio of $64 \%$, and it was followed by HLA-DR1 with a ratio of $28 \%$. Although frequency of SE was higher than our results, the frequency of HLA-DRB1 were similar to ours. Bongi et al. (15) studied an Italian population with 264 RA patients and found the frequency of SE as $46 \%$ and the frequencies of HLA-DR4 and HLADR1 were the same $(22 \%)$. When we look at the literature, it is observed that similar results have been obtained in studies conducted on different populations. To illustrate, SE was found in $59 \%$ of RA patients in Germany, double copy SE was detected in $17.5 \%$ of these patients and HLA-DR4 was the most frequent share epitope producing gene with a ratio of $35 \%$ (16). In Mexican population, frequency of SE was found as $64,3 \%$ in RA patients and the most frequent SE coding gene was found as HLA-DR4 (17). On the other hand, dissimilar to the results obtained in other populations, in a study of loannidis et al. (18) from our neighbor country, Greece, HLD-DR1 gene was found to be more frequent than DR4 and frequency of SE was $44 \%$ in RA patients.

When homozygous/heterozygous carriage of these genes in SE positive RA patients was studied, $70 \%$ of 30 SE positive RA patients were simple heterozygous (35\% of all RA patients), ratio of homozygosity was $20 \%$ ( $10 \%$ of all RA patients) and ratio of those carrying double copy SE was $30 \%$ (15\% of all patients). In a study conducted in our country and published by Kınıklı et al. (4), the ratio of homozygosity was

Table 3. Percentage Distribution of anti CCP (cut-off level $25 \mathrm{IU} / \mathrm{ml}$ ) and RF (cut-off level $20 \mathrm{IU} / \mathrm{ml}$ ) in SE+ and SE(-) patients, and odds ratio of Anti-CCP and RF in the presence of SE

\begin{tabular}{|c|c|c|c|c|c|c|c|c|}
\hline & $\begin{array}{l}\text { Anti-CCP-2 } \\
<25 \mathrm{IU} / \mathrm{ml}\end{array}$ & $\begin{array}{l}\text { Anti-CCP-2 } \\
\geq 25 \mathrm{IU} / \mathrm{ml}\end{array}$ & $\begin{array}{c}\text { *OR } \\
(\% 95 \mathrm{Cl})\end{array}$ & $\begin{array}{c}P \\
\text { Value }\end{array}$ & $\begin{array}{l}\mathrm{RF}<20 \\
\mathrm{IU} / \mathrm{mL}\end{array}$ & $\begin{array}{l}\mathrm{RF} \geq 20 \\
\mathrm{IU} / \mathrm{mL}\end{array}$ & $\begin{array}{c}\text { *OR } \\
(\% 95 \mathrm{Cl})\end{array}$ & $\begin{array}{c}P \\
\text { Value }\end{array}$ \\
\hline \multirow[t]{2}{*}{ SE negative ( $n: 30)$} & 12 & 18 & 1 & $>0.05$ & 6 & 24 & 1 & $>0.05$ \\
\hline & $(40 \%)$ & $(60 \%)$ & & & $(40 \%)$ & $(53.3 \%)$ & & \\
\hline \multirow[t]{2}{*}{ SE positive (n:30) } & 4 & 26 & 4,3 & $P=0.039$ & 9 & 21 & 1.28 & $>0.05$ \\
\hline & $(\% 13.3)$ & $(\% 86.7)$ & $(1.2-15.6)$ & & $(60 \%)$ & $(46.7 \%)$ & $(0.76-2.16)$ & \\
\hline
\end{tabular}

SE: Shared Epitope, anti-CCP: Cyclic citrullinated peptide antibodies, * OR: Odds Ratio, Cl: Confidence Interval, RF: Rheumatoid factor, anti-CCP: Cyclic citrullinated peptide antibodies 
Table 4. Ratio of RF and/or anti-CCP in patients with Rheumatoid Arthritis

\begin{tabular}{lcc}
\hline & $\begin{array}{c}\text { Number of } \\
\text { patients } \\
(n=60)\end{array}$ & $\begin{array}{c}\text { Ratio in all } \\
\text { patients }\end{array}$ \\
\hline $\mathrm{RF} \geq 20 \mathrm{IU} / \mathrm{mL}$ & 45 & $\% 75$ \\
Anti-CCP-2 $\geq 25 \mathrm{IU} / \mathrm{mL}$ & 44 & $\% 73.3$ \\
$\mathrm{RF} \geq 20 \mathrm{IU} / \mathrm{ml}$ or & 52 & $\% 86.7$ \\
Anti-CCP-2 $\geq 25 \mathrm{IU} / \mathrm{mL}$ & & $\% 13.3$ \\
$\mathrm{RF}<20 \mathrm{IU} / \mathrm{mL}$ and & 8 & $\% 61.6$ \\
Anti-CCP-2 $<25 \mathrm{IU} / \mathrm{mL}$ & & \\
$\mathrm{RF} \geq 20 \mathrm{IU} / \mathrm{ml}$ and & 37 & \\
Anti-CCP-2 $\geq 25 \mathrm{IU} / \mathrm{mL}$ & & \\
\hline RF: Rheumatoid factor, anti-CCP: Cyclic citrullinated peptide antibodies
\end{tabular}

found as $49 \%$ in all RA patients and level of simple heterozygosity was low with a ratio of $13 \%$.

In our study, a significant correlation was found between anti-CCP positivity and presence of SE in RA patients ( $p=0.0399) .26(86.7 \%)$ of 30 SE positive patients were found to be anti-CCP positive. These results support the current knowledge in literature. Kaltenhauser et al. (16) reported that RA patients carrying SE synthesizes anti-CCP in higher concentrations. Van der Helm-van Mil et al. (19) reported in a study on undifferential arthritis patients that SE did not independently contribute to RA development but rather contributed to the development of anti-CCP which caused a progression in RA. To prove this claim, they showed that presence of anti-CCP was significantly associated with RA development both in SE positive and SE negative patients with undifferentiated arthritis. A similar result was obtained in a study of Huizinga et al. (8) where they included 408 RA patients and reported presence of SE was associated only with anti-CCP positive RA with no such association in anti-CCP negative patients. However, differently from the study of Van der Helm-van Mil et al. $(18,19)$ he reported that double copy SE increased anti-CCP titer. In our study, we determined an association of SE presence with anti-CCP positivity and titer. However, we found that carrying double copy SE did not significantly increase the titer compared to RA patients carrying single copy SE. This could have been resulted from the statistically insignificant number of patients carrying double copy SE (9 patients) in our study.

Cruyssen et al. (20) reported that the association between SE and anti-CCP was more significant compared to the one between SE and RF. Vries et al. (21) suggested that SE was associated only with anti-CCP positive RA and the association between SE and RF was secondary to that based on observation that both RF and anti-CCP were positive in most of the cases studied. The hypothesis that MHC class II molecules expressing SE bind citrullinated peptides and expose these to $\mathrm{T}$ cells; and thus $\mathrm{T}$ cells help or trigger mutation of $B$ cells synthesizing anti-CCP is the most recognized cause of this relation $(8,21)$. For this reason, due to increased affinity of SE positive DRB1 molecule to citrullinated peptide, it has been suggested that SE is associated only with anti-CCP(+) RA (21).

Related to this, we found that SE positive RA patients had four folds (TRR (OR) 4.33) increased risk of anti-CCP synthesizing compared to SE negative patients. This is close to the risk ratios reported in other studies in the literature. Huizinga et al. (8) found an odds ratio of 4.37 between antiCCP positivity and carrying SE, and Van Galen et al. (1) found the risk as 3.3. On the contrary, we have found a much lower odds ratio (OR:1.8) for SE positivity involving both antibodies (both anti-CCP and RF). This result supports Vries et al.'s (21) hypothesis that SE is associated only with anti-CCP positive RA, and a mild association between SE and $\mathrm{RF}$ is secondary to the association between SE and anti-CCP.

Many studies including ours have shown anti-CCP synthesizing in SE positive patients although it was not as high as the one observed in SE negative RA patients $(8,16)$. In our study, although not as frequent as the one observed in SE positive patients, we observed anti-CCP antibody in SE negative patients too. This could be attributed to the fact that $\mathrm{MHC}$ molecules carrying SE are not the only epitope group that has high affinity to citrullinated peptides during rheumatoid inflammation. As a matter of fact, it has been reported that HLA-DRB1 genes account for only $30 \%$ of the genetic risk in RA (22). In our study, anti-CCP antibody was not detected in 4 (13.4\%) SE positive RA patients. This could be attributed to the facts that our patient group was heterogenous with respect to duration of disease and some patients with early onset had not enough time for anti-CCP synthesis. Decreased anti-CCP sensitivity in early RA and increased anti-CCP sensitivity (approximately $80 \%$ ) in longstanding RA are evidences demonstrating that AntiCCP sensitivity takes time in RA patients (23).

As a result, we may think that $\mathrm{SE}$ is a conventional immune response gene facilitating anti-CCP synthesis. Another important result of our study is that none of those 60 people in healthy control group were found to have anti-CCP. When specificity of Anti-CCP for RA is studied, it is observed that researchers using different cohort groups have reported very high ratios between $96 \%$ and $99 \%$ (23). In a study of 83 RA patients and 140 non-RA patients, Tampoia et al. (24), using 2 nd generation (anti-CCP2) kit just like us, found anti-CCP sensitivity as $67,5 \%$ and specificity as $99,3 \%$. This is an excellent result for a diagnostic test. As our control group included healthy and probably relatively few number of people (60 people), specificity of Anti-CPP for RA was found as $100 \%$. Although sensitivity of the RF, the classical antibody of the disease, was at the same level, value of anti-CCP is better understood when it is considered that specificity 
of RF is $75-80 \%$. Another advantage of this novel antibody is that it can be detected in RF negative patients too and facilitate diagnosing RA at an early stage $(23,25)$. Likewise, we found that 7 RA patients were RF negative but anti-CCP positive.

In recent years, anti-CCP antibody has been detected very rarely in some rheumatic diseases and even in infectious cases (in the prognosis of systemic lupus erythematosus, primary Sjögren syndrome, Psoriatic arthritis, juvenile idiopathic arthritis, hepatitis $C$ infection) $(20,23)$. However, for all these non-RA situations, titers have been reported to be lower in general when compared to RA (26). These non-RA positive situations of anti-CCP have led to some hypotheses. These people may have latent RA (overlap syndrome) along with non-RA disease $(9,20)$. Another reason could be the fact that antibody kit used binds non-specifically to citrullinated peptides created in other diseases. We believe that it would be useful to repeat the test by using another commercial kit in patients without arthritis and where RA is not suspected.

At least one of the two antibodies (anti-CCP and RF) was positive in $\mathbf{8 6 . 7 \%}$ of our RA patients. This is a higher ratio compared to their individual isolated sensitivity of $75 \%$. In fact, it is frequently reported in literature that using these two antibodies together leads to an increased diagnostic and prognostic value $(9,23,27)$. Also, we found that having one of these antibodies was associated with a 5.3 fold increased risk of having the other antibody. Similarly, Irigoyen et al. (28) and Koca et al. (29) found odd-ratio between RF and anti-CCP as 22.7 and 15.4, respectively. We think that these results reflect autoimmune nature of RA. Vallbracht et al. (23) reported that using both markers together facilitates deciding on initiating an early DMARD treatment along with having an increased diagnostic value due to association of both markers with the disease. We think that a better decision can be made by taking into account parameters such as SE presence, positive family history, severity of erosion in early stages of the disease along with autoantibodies.

\section{Conclusion}

The results of the present study revealed that in Turkish patients with RA, SE with DRB1 genes is significantly related with production of CCP antibodies. The diagnostic sensitivity and specificity of anti-CCP for RA is determined as $73.3 \%$ and $100 \%$ respectively.

\section{Conflict of Interest}

No conflict of interest is declared by the authors.

\section{References}

1. van Gaalen FA, van Aken J, Huizinga TWJ, Schreuder GM, Breedveld FC, Zanelli E, et al. Association between HLA class II genes and autoantibodies to cyclic citrullinated Peptides (CCPs) influences the severity of rheumatoid arthritis. Arthritis Rheum 2004; 50: 2113-21.

2. Firestein G.S. (çeviren) Seçkin B ,Bașaran P. Romatoid artritin etyoloji ve patogenezi. In: Arasıl T(Ceviri editörü). Kelley Romatoloji. Ankara: Güneș Kitapevi, 2006; 996-1042.

3. Gregersen PK. (çeviren) Gökoğlu F. Yorgancıoğlu R. Romatizmal Hastalıkların Genetiği. In: Arasıl T (Çeviri editörü). Kelley Romatoloji. Ankara: Güneș Kitabevi, 2006; 276-94.

4. Kınıklı G. Romatoid artritli hastalarda tanı ve tedavi yönünden genetik bulguların değerlendirilmesi (proje,2001-K-120210). Ankara: Ankara Üniversitesi 2004; 1-18.

5. Uçar F, Ovalı E, Değer O. MHC gen kompleksi ve HLA doku tiplemesinin testlerinin önemi, İbni Sina Tıp Dergisi 2001; 6: 117-27.

6. Teller K, BudhaiL, Zhang M, Haramati N, Keiser HD, Davidson A. HLA-DRB1 and DQB typing of Hispanic American Patients with rheumatoid arthritis: The 'shared epitope' hypothesis may not apply. J Rheumatol 1995; 23: 1363-8.

7. McDanie DO, Alarcon GS, Prat PW, Reveille JD. Most Africanamerican patients do not have the rheumatoid antigenic determinant (epitope). Ann Intern Med 1995; 123: 181-7.

8. Huizinga TW, Amos $\mathrm{Cl}$, van der Helm-van Mil AH, Chen W, van Gaalen FA, Jawaheer $D$, et al. Refining the complex rheumatoid arthritis phenotype based on specificity of the HLA-DRB1 shared epitope for antibodies to citrullinated proteins. Arthritis Rheum 2005; 52: 3433-8.

9. Zendman AJ, van Venrooij WJ, Pruijin GJ. Use and significance of anti-CCP autoantibodies in rheumatoid arthritis. Rheumatology (Oxford) 2006; 45: 20-5.

10. Berglin E, Padyukov L, Sundin U, Hallmans G, Stenlund H, Van Venrooij WJ, et al. A combination of autoantibodies to cyclic citrullinated peptide (CCP) and HLADRB1 locus antigens is strongly associated with future onset of rheumatoid arthritis. Arthritis Res Ther 2004; 6: R303-8.

11. Cantagrel A, Constantin A, Vincent $C$, Abbal M, Laroche $M$, Ohayon $E$, et al. Rheumatoid factor and antikeratin antibody are independent from presence of DR4 or DR1 in rheumatoid arthritis. Rev Rhum Engl 1999; 66: 20-3.

12. Goldbach-Mansky R, Lee J, McCoy A, Hoxworth J, Yarboro C, Smolen JS, et al. Rheumatoid arthritis associated autoantibodies in patients with synovitis of recent onset. Arthritis Res 2000; 2: 236-43.

13. Bas S, Perneger TV, Mikhnevitch E, Seitz M, Tiercy JM, RouxLombard $\mathrm{P}$, et al. Association of rheumatoid factors and anti-filaggrin antibodies with severity of erosions in rheumatoid arthritis. Rheumatology 2000; 39: 1082-8.

14. Correa PA, Tobon GJ, Citera G, Cadena J, Schneeberger E, Camargo JF, et al. Anti-cyclic citrullinated peptide antibodies in rheumatoid arthritis: relation with clinical features, cytokines and HLA-DRB1. Biomedica 2004; 24: 140-52.

15. Bongi SM, Porfirio B, Rombolà G. Shared-epitope HLADRB1 alleles and sex ratio in Italian patients with rheumatoid arthritis. Joint Bone Spine 2004; 71: 24-8. 
16. Kaltenhäuser S. Piere M. Arnold S. Kamprad M, Baerwald C, Häntzschel H. Antibodies against cyclic citrullinated peptide are associated with the DRB1 shared epitope and predict joint erosion in rheumatoid arthritis. Rheumatology (Oxford) 2007; 46: 100-4.

17. Ruiz-Morales JA, Vargas-Alarcón G, Flores-Villanueva PO, Villarreal-Garza C, Hernández-Pacheco G, YamamotoFurusho JK, et al. HLA-DRB1 alleles encoding the "shared epitope" are associated with susceptibility to developing rheumatoid arthritis whereas HLA-DRB1 alleles encoding an aspartic acid at position 70 of the beta-chain are protective in Mexican Mestizos. Hum Immunol 2004; 65: 262-9.

18. Ioannidis J. Tarassi K, Papadopoulos IA, Voulgari PV, Boki KA, Papasteriades CA, et al. Shared epitopes and rheumatoid arthritis: Disease associations in Greece and meta-analysis of Mediterranean European populations. Semin Arthritis Rheum 2002;31: 361-70.

19. van der Helm-van Mil AH, Verpoort KN, le Cessie $S$, Huizinga TW, de Vries RR, Toes RE.The HLA-DRB1 shared epitope alleles are primarily a risk factor for anti-cyclic citrullinated peptide antibodies and are not an independent risk factor for development of rheumatoid arthritis. Arthritis Rheum 2006; 54: 1117-21.

20. Vander Cruyssen B, Peene I, Cantaert T, Cantaert T, Hoffman IE, De Rycke L, et al. Anti-citrullinated protein/ peptide antibodies (ACPA) in rheumatoid arthritis: specificity and relation with rheumatoid factor. Autoimmun Rev 2005; 4: 468-74.

21. de Vries RR, Huizinga TW, Toes RE. HLA and RA revisited: citrullinated food for the SE hypothesis, the DR6 effect, and NIMA.Hum Immunol 2006; 67: 454-9.
22. Morel J, Combe B. How to predict prognosis in early rheumatoid arthritis. Best Pract Res Clin Rheumatol 2005; 19: 137-46.

23. Vallbracht I, Rieber J, Oppermann M, Förger F, Siebert U, Helmke $K$, et al. Diagnostic and clinical value of anti-cyclic citrullinated peptide antibodies compared with rheumatoid factor isotypes in rheumatoid arthritis. Ann Rheum Dis 2004; 63: 1079-84.

24. Tampoia M, Brescia V, Fontana A, Maggiolini P, Zucano A, Pansini N. Proteomic: new advances in the diagnosis of rheumatoid arthritis. Clin Chim Acta 2005; 357: 219-25.

25. Vossenaar ER., van Venrooij WJ. Anti-CCP antibodies, a highly spesifik marker for (early) rheumatoid arthritis. Clinical and Applied Immunology Reviews 2004; 4: 239-62.

26. Bell DA. Can we rely on anti-citrulline antibody determination for the diagnosis of early rheumatoid arthritis? J Rheumatol 2006; 33: 2369-71.

27. Berglin E, Johansson T, Sundin U. Jidell E, Wadell G, Hallmans G,et al Radiological outcome in rheumatoid arthritis is predicted by presence of antibodies against cyclic citrullinated peptide before and at disease onset, and by IgA-RF at disease onset. Ann Rheum Dis 2006; 65: 453-8.

28. Irigoyen $\mathrm{P}$, Lee AT, Wener MH, Li W, Kern M, Batliwalla F, et al. Regulation of anti-cyclic citrullinated peptide antibodies in rheumatoid arthritis: contrasting effects of HLA-DR3 and the shared epitope alleles. Arthritis Rheum 2005; 52: 3813-8.

29. Koca SS, Akbulut H, Dag S. Artas H, Isik A. Anti-cyclic citrullinated peptide antibodies in rheumatoid arthritis and Behçet's disease. Tohoku J Exp Med 2007; 213: 297-304. 